\title{
PENGARUH UMPAN BALIK POSITIF MEDIA SOSIAL TERHADAP SELF ESTEEM PADA MAHASISWA PENGGUNA INSTAGRAM DI UNIVERSITAS NEGERI MAKASSAR
}

\author{
Hasri Isrami A. Syamsu', Lukman², Muh. Nur Hidayat Nurdin ${ }^{3}$ \\ Fakultas Psikologi, Universitas Negeri Makassar \\ (dayat20858@gmail.com) ${ }^{3}$
}

\begin{abstract}
Abstrak. Frekuensi umpan balik positif (jumlah like) akan memengaruhi self esteem dari individu. Salah satu media sosial yang digunakan individu untuk berbagi foto/video ialah Instagram. Tujuan dari penelitian ini adalah untuk mengetahui pengaruh umpan balik positif media sosial dengan self esteem pada mahasiswa pengguna Instagram di Universitas Negeri Makassar. Pengaruh respon dipengaruhi oleh banyaknya respon (jumlah like yang diterima dari pengguna Instagram lain). Subjek penelitian ini berjumlah 295 orang berjenis kelamin perempuan (usia 18-21 tahun) yang berasal dari beberapa fakultas dalam lingkup Universitas Negeri Makassar. Metode pengumpulan data yang digunakan dalam penelitian ini dilakukan melalui skala penelitian dan angket yang berisi pertanyaan tertutup, kepada mahasiswa pengguna Instagram di Universitas Negeri Makassar dengan menggunakan teknik incidental sampling. Teknik analisis yang digunakan pada penelitian ini adalah regresi model logistik ordinal, berdasarkan hasil analisis diperoleh nilai koefisien korelasi $(\mathrm{r}=0,000)$ dan signifikansi $(\mathrm{p}>0,05)$, artinya tidak terdapat pengaruh positif umpan balik positif terhadap self esteem pada mahasiswa pengguna instgaram, semakin rendah umpan balik positif media sosial yang diperoleh maka makin rendah self esteem yang dimiliki individu. Penelitian ini memberi gambaran mengenai umpan balik positif media sosial terhadap self esteem individu, khususnya pada umpan balik positif media sosial yang dapat berpengaruh terhadap self esteem.
\end{abstract}

Kata kunci: self esteem, umpan balik positif media sosial, mahasiswa pengguna Instagram di Univeritas Negeri Makassar.

Abstract. The frequency of positive feedback (number of likes) will affect the self-esteem
of the individual. One of the social media that individuals use to share photos/videos is
Instagram. The purpose of this study was to determine the effect of positive social media
feedback with self-esteem on Instagram users at Makassar State University. The effect of
the response is influenced by the number of responses (number of likes received from
other Instagram users). The subjects of this study were 295 women (ages $18-21$ years)
who came from several faculties within Makassar State University. Data collection
methods used in this study were carried out through a research scale and questionnaire
containing closed questions, to students using Instagram at Makassar State University
using incidental sampling techniques. The analysis technique used in this study is the 
ordinal logistic regression model, based on the results of the analysis obtained the value of the correlation coefficient $(r=0,000)$ and significance $(p>0.05)$, meaning that there is no positive effect of positive feedback on self-esteem on student users of Instagram, the lower the positive social media feedback obtained, the lower the self-esteem that an individual has. This study provides an overview of positive social media feedback on individual self-esteem, especially on positive social media feedback that can affect self-esteem.

Keywords: self-esteem, positive social media feedback, Instagram user students at Makassar State University.

\section{PENDAHULUAN}

Kemudahan mengakses internet melalui handphone membuat masyarakat lebih mudah menggunakan berbagai fitur media sosial. Media sosial merupakan media online yang memungkinkan penggunanya merasakan kemudahan dalam berbagi momen, informasi, dan cerita dalam dunia maya. Perkembangan teknologi saat ini mendorong masyarakat untuk lebih mudah dalam berinteraksi dengan rekan-rekan, baik yang dekat maupun jauh. Saat ini telah tersedia berbagai macam aplikasi media sosial yang dapat menyambungkan komunikasi antara individu yang satu dengan yang lain melalui media internet. Data penggunaan internet untuk membangun dan mempertahankan suatu hubungan sosial dalam beberapa tahun terakhir meningkat dengan pesat (Kominfo.com, 2017).

Burrow dan Rainone (Valkenburg, Peter \& Schouten, 2006) menemukan bahwa situs-situs jejaring sosial pun menjadi semakin popular bagi remaja untuk membangun hubungan. Ragam hubungan yang dibangun dalam situs jejaring sosial pun berbeda-beda, misalnya terdapat situs untuk berkencan yang tujuan utamanya untuk membantu individu mencari pasangan hidup, seperti Match.com. Terdapat situs jejaring sosial yang mengumpulkan individu yang memiliki kesamaan minat, misalnya Bookcrossing.com. Situs jejaring sosial yang tujuan utamanya untuk membangun dan mempertahankan hubungan pertemanan antara lain Friendster, MySpace, Facebook, Twitter, Path, WhatsApp, Line, Blackberry Massanger, dan Instagram.

Selain beberapa menggunakan tersebut, Instagram juga membolehkan pengguna untuk memberikan tanda suka (like) terhadap isi (content) dari apa yang dilihatnya. Kemudahan untuk melakukan liking pada unggahan (post) membuat instagram semakin disukai. Pengaruh like terhadap pengguna lain menunjukkan hasil yang positif. Misalnya studi yang dilakukan oleh Valkenburg, Peter, dan Schouten (2006) membuktikan bahwa menerima informasi dari orang lain terhadap konten yang diunggah di media sosial, dapat meningkatkan harga diri (self esteem), kebahagiaan (well-being), dan berhubungan negatif dengan kesepian. Jumlah teman di media sosial memiliki hubungan positif dengan kebahagiaan (subjective well-being) (Kim \& Lee, 2011).

Rosenberg (Murk,2006) mengemukakan bahwa self esteem merupakan suatu evaluasi positif ataupun negatif terhadap diri sendiri (self). Coopersmith (1967) mengemukakan bahwa self esteem merupakan evaluasi yang dibuat oleh individu mengenai hal-hal yang berkaitan dengan dirinya yang diekspresikan melalui suatu bentuk penilaian yang positif, dan menunjukkan tingkat dimana individu meyakini dirinya sebagai individu yang mampu, penting dan berharga.

Data awal yang diperoleh peneliti dari 46 subjek mahasiswa UNM yang aktif menggunakan Instagram, menunjukkan bahwa 38 subjek memiliki tingkat self esteem yang rendah. Ke-tiga puluh delapan (38) responden menyatakan memiliki 
penilaian diri yang kurang terhadap kemampuan yang dimiliki, serta belum mampu menerima dirinya dengan baik. Responden mengaku kurang mampu mengekspresikan dirinya dalam kehidupan sosial. Responden juga menyatakan bahwa mereka memilih media sosial sebagai sarana untuk melakukan interaksi dengan orang lain karena memiliki self esteem yang rendah.

Greenberg, Solomon, Pyszczynski, Rosenblatt, Burling, Lyon, dan Pinel (1992) menunjukkan bahwa orang yang baru saja menerima umpan balik yang positif tentang kepribadiannya memiliki harga diri yang tinggi, dibandingkan individu lain yang menerima umpan balik negatif atau netral.

Berdasarkan data yang diperoleh peneliti dari 46 subjek mahasiswa aktif di Universitas Negeri Makassar (UNM) yang aktif menggunakan Instagram dijumpai fakta bahwa, frekuensi mengunggah foto/video dilakukan sebanyak 1-5 kali per hari, dan frekuensi penerimaan umpan balik postitif media sosial (like) khususnya Instagram ialah rata-rata 100 likes. Seluruh subjek (46 orang) mengaku menggunakan Instagram karena umpan balik yang diterima di media sosial merupakan hal penting bagi dirinya, dan hal ini merupakan gambaran bahwa individu merasa dianggap, dihargai, dan diterima oleh individu lain (pengguna Instagram lain) Mandhane, Ansari, Shaikh, dan Deolekar (2015) mengemukakan bahwa umpan balik dapat digambarkan sebagai suatu proses yang terdiri atas komunikasi informasi yang diikuti oleh reaksi komunikasi tersebut. Terdapat dua jenis umpan balik, yaitu positif dan negatif.

Kebutuhan mencari perhatian, dan penghargaan dari orang lain dipengaruhi oleh gender. Studi Josephs, Markus, dan Tafarodi (1992) terhadap 43 orang lakilaki dan 47 perempuan mengemukakan hasil bahwa self esteem berbeda dari segi kebutuhan. Self esteem perempuan sangat bergantung terhadap penilaian orang lain, sedangkan pada laki-laki lebih bersifat individual. Perempuan akan lebih mudah untuk terpengaruh dengan jumlah like yang ia terima daripada laki-laki. Burrow dan Rainone (2017) menemukan bahwa umpan balik positif di media sosial (dihitung dari jumlah like yang diterima) dapat meningkatkan penilaian individu bahwa dirinya mendapatkan penerimaan yang baik dari orang lain.

Leary dan Baumeister (2000) mengemukakan bahwa self esteem merupakan sebuah alat ukur yang digunakan individu untuk menilai (melakukan evaluasi) mengenai apa yang dilakukan oleh orang lain. Reitz, Asendorpf, dan Motti-Stefanidi (2016) mengemukakan bahwa sociometer theory lebih menekankan pada kebutuhan individu agar dirinya tidak ditolak, sedangkan studi meta analisis terakhir justru menemukan bahwa self esteem akan meningkat karena individu butuh penerimaan.

Reitz, Asendorpf, dan Motti- Stefanidi (2016) mengemukakan bahwa sociometer theory merupakan teori yang menjelaskan bagaimana self esteem berhubungan dengan rasa suka orang lain. Individu yang memiliki self esteem tinggi akan memengaruhi rasa suka orang lain terhadap dirinya. Semakin tinggi self esteem individu, maka individu akan semakin popular, dan oleh karena hal tersebut individu semakin disukai oleh orang lain.

Berdasarkan hasil penelitian terdahulu mengenai umpan balik positif di media sosial, peneliti menyimpulkan bahwa umpan balik di media sosial akan memiliki pengaruh yang besar untuk meningkatkan self esteem pada pengguna Instagram. Studi yang mengaitkan media sosial dan self esteem sebelumnya menggunakan facebook sebagai media sosial. Pada studi ini, peneliti tertarik untuk meneliti subjek dengan media yang berbeda, yaitu pengguna Instagram.

Berdasarkan uraian di atas, maka hipotesis pada penelitian ini adalah terdapat pengaruh positif umpan balik positif di 
media sosial dengan self esteem mahasiswa pengguna instagram. Semakin banyak umpan balik positif (jumlah like) yang diterima di instagram, maka akan semakin tinggi self esteem yang dimiliki oleh mahasiswa pengguna Instagram.

\section{METODE}

Variabel terikat dalam penelitian ini adalah self esteem, self esteem pada diri individu yang dimaksud dalam penelitian ini ialah diperoleh dari penilaian individu terhadap dirinya dari pendapat orang lain (penilaian eksternal) terhadap unggahan foto/video individu di akun Instagram yang dimiliki. Variabel self esteem diukur menggunakan skala self esteem yang dikembangkan oleh Rosenberg (Burrow \& Rainone, 2017).

Variabel bebas dalam penelitian ini adalah umpan balik positif, umpan balik positif dalam penelitian ini merupakan sebuah tindakan yang diperoleh oleh individu untuk dapat meningkatkan harga diri atau perilaku individu untuk dihargai. Umpan balik positif diukur menggunakan angket yang berisi pertanyaan tertutup. Umpan balik positif dalam penelitian ini adalah penting atau tidak penting pengaruh positif dari jumlah like yang diterima di Instagram dan rata-rata jumlah like yang diperoleh setelah mengunggah video atau foto di Instagram (Burrow \& Rainone, 2017).

Populasi dalam penelitian ini yaitu mahasiswa akitf Universitas Negeri Makassar yang memiliki akun aktif Instagram dengan karakteristik subjek berjenis kelamin perempuan (berusia antara 18-21 tahun) dan aktif mengunggah foto/ video 1-5 kali dalam sepekan di akun Instagram yang dimiliki. Metode pengumpulan data yang digunakan dalam penelitian ini menggunakan teknik incidental sampling dengan dua jenis skala yakni skala umpan balik yang berisi pertanyaan tertutup (1. Apakah like yang anda peroleh setelah mengunggah foto/video di Instagram dapat memberikan pengaruh yang positif terhadap diri anda? 2. rata-rata berapa like yang anda peroleh pada setiap foto/ video yang anda unggah di Instagram?), dan skala self esteem yang berjenis skala Likert dengan rentang 14.

Reliablitas skala alpha yang diperoleh dari hasil penelitian terhadap skala self esteem yang diberikan kepada 295 subjek yang terdiri dari 9 aitem dan memiliki nilai cronbach's Alpha sebesar 0,741 yang berarti bahwa skala self esteem memiliki reliabel yang cukup bagus atau dapat dipercaya. Terdapat 1 aitem yang gugur setelah melakukan uji coba skala terhadap 82 subjek penelitian sehingga tersisa jumlah aitem sebesar 9 dari 10 aitem. Skala umpan balik positif disusun dengan mengacu dari skala penelitian dari Burrow dan Rainone (2017) yang berisi pertanyaan tertutup dengan pilihan jawaban berjenis ordinal.

Validasi skala penelitian ini menggunaan formula Aiken's $\mathrm{V}$ yang diperoleh dari semua aitem skala self esteem berada pada rentang 0,812 sampai dengan 0,937. Hasil tersebut membuktikan bahwa tingkat validasi yang telah dilakukan oleh professional judgement tergolong baik.Teknik analisis data pada penelitian ini menggunakan uji analisis deskriptif dan uji hipotesis dengan menggunakan teknik regresi model logistik ordinal $(p>0,5)$.

\section{HASIL DAN PEMBAHASAN}

Subjek dalam penelitian ini berjumlah 295 orang mahasiswa aktif Universitas Negeri Makassar yang memiliki akun aktif Instagram yang telah ditentukan peneliti. 
Tabel 1. Respon subjek terhadap pengaruh positif yang diperoleh di Instagram

\begin{tabular}{ccc} 
Respon & Frekuensi & $\begin{array}{c}\text { Persentase } \\
(\boldsymbol{\%})\end{array}$ \\
Ya & 227 & 76,95 \\
Tidak & $\underline{68}$ & $\underline{23,05}$ \\
\cline { 1 - 1 } Jumlah & $\underline{\mathbf{2 9 5}}$ & $\underline{\mathbf{1 0 0}}$ \\
\hline
\end{tabular}

Berdasarkan tabel 1 di atas dapat diketahui jumlah subjek terdiri atas 227 subjek menyatakan bahwa like yang diperoleh di Instagram dapat memberikan pengaruh positif terhadap diri subjek, dengan presentase sebesar $76,95 \%$. Subjek dalam penelitian ini yaitu mahasiswa Universitas Negeri Makassar yang memiliki akun Instagram, peneliti menemukan di lapangan bahwa like yang diperoleh dari Instagram memiliki pengaruh positif terhadap subjek.

Hasil wawancara kepada 30 subjek penelitian bahwa motif individu memperoleh umpan balik berupa like pada unggahan foto/video di akun Instagram untuk mencari perhatian dan pengharagaan dari orang lain yang bertujuan meningkatkan kebutuhan individu untuk diterima di lingkungan. Oleh karena itu umpan balik berupa like yang diperoleh di media sosial, khususnya di instagram dianggap penting oleh individu. Stefanone, Lackaff, dan Rosen (2011) mengemukakan bahwa terdapat motif sosial individu, yaitu mencari perhatian dan mencari penghargaan dari orang lain.
Tabel 2. Deskriptif subjek penelitian berdasarkan jumlah like yang diperoleh di Instagram

\begin{tabular}{ccc}
$\begin{array}{c}\text { Jumlah } \\
\text { like }\end{array}$ & Frekuensi & $\begin{array}{c}\text { Persentas } \\
\text { e }(\%)\end{array}$ \\
\cline { 1 - 1 } $0-50$ & 95 & 32,20 \\
$51-100$ & 115 & 38,98 \\
$101-150$ & 44 & 14,91 \\
$151-200$ & 21 & 7,12 \\
$>200$ & 20 & $\underline{6,78}$ \\
\cline { 1 - 1 } Jumlah & $\underline{\mathbf{2 9 5}}$ & $\underline{\mathbf{1 0 0}}$ \\
\hline
\end{tabular}

Berdasarkan tabel 2 dapat diketahui bahwa 115 subjek memiliki jumlah like sebesar 51-100 like (38,98\%). Peneliti menemukan bahwa jumlah like terbanyak yang dimiliki oleh subjek ialah sebesar 51100 like. Dapat diindikasikan bahwa ratarata jumlah like yang diperoleh setelah mengunggah foto/video di Instagram termasuk dalam kategori rendah 51-100 like $(38,98 \%)$ dilihat dari urutan kategorisasirata-rata jumlah like.

Bevan, Pfyl, dan Barclay (2012) mengemukakan bahwa penolakan (rejection) pada media sosial dapat menciptakan emosi negatif. Burrow dan Rainone (2017) menyatakan bahwa menerima umpan balik positif merupakan tanda penerimaan dalam lingkungan sosial, dapat diindikasikan bahwa harga diri akan meningkat sebagai manfaat dari jumlah like yang diterima pada foto- foto pribadi yang diunggah di sosial media.

Tabel 3. Data hipotetik selfesteem

\begin{tabular}{llccc}
\hline $\begin{array}{c}\text { Variab } \\
\text { el }\end{array}$ & & \multicolumn{3}{c}{ Hipotetik } \\
\cline { 1 - 1 } $\begin{array}{c}\text { Self } \\
\text { esteem }\end{array}$ & Min & Max & Mean & SD \\
\cline { 5 - 6 } & $\underline{96}$ & $\underline{36}$ & $\underline{40,5}$ & $\underline{4,5}$
\end{tabular}


Tabel 4. Kategorisasi dan interpretasi skor self esteem

\begin{tabular}{ccc} 
Kategori & Frekuensi & $\begin{array}{c}\text { Persentase } \\
(\boldsymbol{\%})\end{array}$ \\
Tinggi & 0 & 0 \\
Sedang & 1 & 0,34 \\
Rendah & $\underline{294}$ & $\underline{99,66}$ \\
\cline { 1 - 1 } Jumlah & $\underline{\underline{\mathbf{2 9 5}}}$ & $\underline{\mathbf{1 0 0}}$ \\
\hline
\end{tabular}

Berdasarkan tabel 4 data self esteem yang ditemukan oleh peneliti di lapangan menunjukkan bahwa self esteem subjek penelitian berada pada kategori rendah $(99,66 \%)$. Data dari hasil wawancara pada 10 orang subjek penelitian di lapangan pengguna media sosial mengenai self esteem yang dimiliki menyatakan bahwa subjek memiliki rasa percaya diri yang rendah dalam menilai kemampuan yang dimiliki. Kepercayaan diri yang rendah disebabkan perasaan takut dinilai tidak benar di hadapan orang lain, kurang prestasi yang dapat dibanggakan, dan minimnya manfaat yang diberikan bagi lingkungan sekitar.

Alwisol (2004) mengemukakan bahwa self esteem yang kurang dapat menimbulkan frustrasi karena kebutuhan self esteem yang dimiliki individu tidak terpenuhi dan akan menimbulkan perasaan serta sikap inferior, canggung, lemah, pasif, tergantung pada orang lain, penakut, tidak mampu mengatasi tugas-tugas dalam kehidupan dan kurang baik dalam bergaul.

Pengaruh lain dari self esteem yang rendah adalah ketidakmampuan individu dalam mengekspresikan dirinya di kehidupan sosial secara langsung, sehingga memilih media sosial sebagai sarana yang tepat untuk berekspresi. Subjek mengaku bahwa akan menampilkan yang terbaik dari dirinya untuk diperlihatkan pada pengguna media sosial khususnya
Instagram dari unggahan foto/video dan berharap agar mendapatkan umpan balik yang positif dari media sosial.

Isi dari umpan balik (jumlah like) yang diperoleh subjek melalui unggahan foto/video di media sosial khususnya Instagram dapat memberi pengaruh terhadap self esteem yang dimiliki. Sejalan dengan teori yang dikemukakan oleh Adler, Rogers, Fromm dan Erikson (Ewen, 2009) mengemukakan bahwa Individu berusaha untuk mencapai self esteem terhadap keyakinan dan penguasaan lingkungan, memperoleh pengakuan serta penghargaan dari orang lain.

Hasil uji hipotesis antara varibel umpan balik positif dengan self esteem menunjukkan bahwa skor skor korelasi $r$ $=0,000$ dengan nilai signifikansi ( $\mathrm{p}>0,05)$ ditemukan bahwa menunjukkan koefisien korelasi yang sangat rendah, artinya tidak terdapat pengaruh positif umpan balik positif terhadap self esteem pada mahasiswa pengguna instgaram, semakin rendah umpan balik positif media sosial yang diperoleh maka makin rendah self esteem yang dimiliki individu.

Hasil uji hipotesis juga didukung oleh hasil wawancara pada 30 subjek penelitian di lapangan menyatakan bahwa, umpan balik positif yang diperoleh di media sosial sangat penting. Umpan balik tersebut bukan hanya jumlah like saja, tetapi terdapat banyak jenis, seperti komentar poisitif, jumlah teman yang responsif (memberikan informasi yang positif seperti), informasi seputar lingkungan dan lifestyle (gaya hidup) yang sedang trend (banyak digunakan orang lain), referensi makanan enak, referensi mengenai dekorasi rumah unik, referensi tempat makan dan berkumpul bersama teman ataupun keluarga, referensi untuk para pecinta otomotif, juga untuk para pelaku yang sedang menjalani bisnis (freelancer, influencer, 
dan enterpreneur)dapat memeroleh keuntungan berupa uang. Hasil wawancara terhadap 30 subjek penelitian di lapangan, menyatakan bahwa umpan balik positif yang diterima di media sosial khususnya di Instagram bukan hanya dapat memengaruhi self esteem seseorang, tetapi juga dapat meningkatkan eksistensi karena memiliki banyak jumlah teman dan like.

Kepercayaan diri karena memeroleh apresiasi yang baik dari pengguna Instagram, dan bagi para pelaku bisnis akan meningkatkan jumlah pendapatan. Semakin banyak umpan balik positif yang diterima seseorang melalui media sosial juga akan dapat meningkatkan kinerja seseorang.

Hasil wawancara terhadap 30 subjek penelitian di lapangan menyatakan bahwa tujuan dalam mengakses instagram berbeda beda, sepeti diketahui tujuan individu menagkses instagram untuk mencari penghasilan (enterprenuer, influencer, dan creativeprenuer), hanya mencari kesenangan, mencari popularitas (memiliki banyak teman), mencari referensi terentu (lifestyle), dan menyebarkan hal positif.

Burrow dan Rainone (2017) membuktikan bahwa purpose in life individu memiliki hubungan yang kuat terhadap self esteem individu. Terdapat tujuan individu menggunakan media sosial berbeda beda, sehingga pengaruh terhadap self esteem. Self broadcasting perspective (Reitz, Motti-Stefanidi, \& Asendorpf, 2016), ekspresi diri individu di media sosial menjadi bagian dari evaluasi diri individu secara sosial. Evaluasi yang positif akan meningkatkan self esteem dan meningkatkan popularitas individu karena secara sosial individu merasa (berdasarkan penilaian orang lain - judges by others) dirinya disukai.

Leary dan Baumeister (2000) mengemukakan bahwa self esteem merupakan sebuah alat ukur yang digunakan individu untuk menilai (melakukan evaluasi) mengenai apa yang dilakukan oleh orang lain. Sistem tersebut (psychological warning system) merupakan alat yang digunakan untuk memonitor dan merespon tanda-tanda yang relevan bagi individu ketika dirinya berada pada suatu hubungan, tanda tersebut seperti rasa disukai (liking) atau tidak disukai (disliking). Oleh sebab itu, self esteem akan meningkat ketika individu menemukan isyarat apabila individu disukai oleh orang lain.

\section{SIMPULAN DAN SARAN}

Berdasarkan hasil penelitian dapat ditarik kesimpulan bahwa, tidak terdapat pengaruh umpan balik positif media sosial terhadap self esteem mahasiswa pengguna Instagram di Universitas Negeri Makassar. Umpan balik positif media sosial dalam penelitian ini diukur dari jumlah like yang diterima pada saat setelah mengunggah foto/video di Instagram. Umpan balik positif media sosial (Instagram) merupakan salah satu pengaruh self esteem mahasiswa dapat meningkat.

Berdasarkan pembahsan dan kesimpulan penelitian, maka diajukan beberapa saran sebagai berikut:

1. Hasil penelitian menunjukkan bahwa yang memeroleh pengaruh positif antara umpan balik positif terhadap self esteem menunjukkan ketergantungan mahasiswa yang tinggi terhadap media sosial. Oleh karena itu, lingkungan perlu memberikan respon yang positif terhadap individu dalam membentuk karakter dan perilaku yang positif tanpa distraksi dari media sosial dan pendapat orang lain. 
2. Penelitian ini masih tergolong sederhana karena hanya melihat pengaruh umpan balik positif terhadap self esteem mahasiswa di Universitas Negeri Makassar. Peneliti selanjutnya yang ingin meneliti dengan topik yang sama, sebaiknya menggunakan lebih banyak variasi umpan balik positif seperti, jumah teman dan komentar poisitif, dan sebaiknya memberikan intervensi seperti training, workshop, dan metode lain dan melihat dampaknya terhadap peningkatan selfesteem.

3. Bagi peneliti selanjutnya diharapkan menggunakan variasi sampel yang lebih banyak sehingga memeroleh hasil yang lebih luas. Perbandingan antara self esteem pada subjek wanita dan laki-laki, serta antara remaja dan dewasa dapat diaplikasikan, sehingga hasil yang diperoleh lebih luas.

4. Bagi peneliti selanjutnya sebelum meneliti dengan topik yang sama, disarankan dikelompokkan sesuai dengan tujuan individu menggunakan media sosial.

\section{DAFTAR PUSTAKA}

Alwisol. (2004). Psikologi kepribadian (Ed 1). Malang: UMM Press

Burrow, A. L., \& Rainone, N. (2017). How many likes did I get?: Purpose modertes links between positive social media feedback and self-esteem. Journal of Experimental Social Psychology, 69, 232-236.

Bevan, J. L., Pfyl, J., \& Barclay, B. (2012). Negative emotional and cognitive responses to being unfriended on Facebook: An exploratory study. Computers in Human Behavior, 28, 1458-
1464.

Coopersmith, S. (1967). The antecendent of self esteem. San Fransisco: W.H Freeman and Company.

Ewen, R. B. (2009). An introduction to theories of personality ( $\left.7^{\text {th }} \mathrm{ed}\right)$. New York: Psychology Press.

Greenberg, J., Solomon, S., Pyszczynski, T., Rosenblatt, A., Burling, J., Lyon, D., \& Pinel,

E. (1992). Why do people need selfesteem? Converging evidence that self-esteem serves an anxiety-buffering function. Journal of Personality and Social Psychology, 63, 913- 922.

Josephs, R. A., Markus, H. R., \& Tafarodi, R. W. (1992). Gender and self esteem. Journal of Personalitiy and Social Psychology, 63(3), 391-402.

Kim, J., \& Lee, J. E. R. (2011). The facebook paths to happiness: Effects of the number of facebook friends and self- presentation on subjective well- being. CyberPsychology, Behavior, and Social Networking, 14(6), 359-364.

Kominfo. (2017). https://www.kominfo.go.id/con tent/detail/3980/kemkominfopengguna-internet-di- indonesiacapai-82- juta/0/berita_satker (diakses 8 September 2017).

Leary, M. R., \& Baumeister, R. F. (2000). The nature and function of selfesteem: Sociometer theory. In M. P. Zanna (Ed.), Advances in Experimental Social Psychology, 32(pp. 1- 62). San Diego, CA: Academic Press.

Mandhane, N., Ansari, S., Shaikh, T.P., \& Deolekar, S. (2015). Positive feedback: A tool for quality education in field of medicine. International Journal Resorces Medical Science, 3(8), 1868-73.

Murk, C. J. (2006). Self-esteem research, theory, and practice: 
Toward a positive psychology of self-esteem (3rd ed.). New York: Springer Publishing Company.

Reitz, A. K., Motti-Stefanidi, F., \& Asendorpf, J. B. (2016). Me, us, and them: Sociometer theory in a diverse real-life context. Journal of Personality and Social Psychology, 11(6), 908920. Colombia university.

Stefanone, M. A., Lackaff, D., \& Rosen, D. (2011). Contingencies of self-worth and social-networking-site behavior. Cyberpsychology, Behavior, and Social Networking, 14(1-2), 41-49.

Valkenburg, P. M., Peter, J., \& Schouten, A. P. (2006). Friend networking sites and their relationship to adolescents' well-being and social selfesteem. Cyberpsychology \& Behavior, 9(5), 584-90. 